University for Business and Technology in Kosovo

UBT Knowledge Center

UBT International Conference

2018 UBT International Conference

Oct 27th, 9:00 AM - 10:30 AM

\title{
Industrial contamination impact on food chain in correlation to poultry eggs
}

Afete-Shala Musliu

University for Business and Technology, afete.musliu@ubt-uni.net

Nexhat Balaj

University for Business and Technology

Sami Makolli

University for Business and Technology

Follow this and additional works at: https://knowledgecenter.ubt-uni.net/conference

Part of the Food Science Commons

\section{Recommended Citation}

Musliu, Afete-Shala; Balaj, Nexhat; and Makolli, Sami, "Industrial contamination impact on food chain in correlation to poultry eggs" (2018). UBT International Conference. 173.

https://knowledgecenter.ubt-uni.net/conference/2018/all-events/173

This Event is brought to you for free and open access by the Publication and Journals at UBT Knowledge Center. It has been accepted for inclusion in UBT International Conference by an authorized administrator of UBT Knowledge Center. For more information, please contact knowledge.center@ubt-uni.net. 


\title{
Industrial contamination impact on food chain in correlation to poultry eggs
}

\author{
Afete-Shala Musliu ${ }^{1}$, Nexhat Balaj ${ }^{1}$, Sami Makolli ${ }^{1}$ \\ ${ }^{1}$ UBT - Higher Education Institution, Lagjja Kalabria p.n., Prishtinë, Kosovë
}

Corresponding author: Email: afete.musliu@ubt-uni.net

\begin{abstract}
Environmental problems related to pollution of soil, food and water have been increased with industrialization. The anthropogenic source of toxic elements in the environment are either as a consequence of mining, smelting and aerosol deposition, or as an outcome of working on the soil such as the application of fertilizer (agriculturally induced), waste pollution via water and landfill sites. Mining is the largest anthropogenic source of toxic elements contamination. The purpose of this paper is to assess the toxic elements (As, $\mathrm{Cd}, \mathrm{Cr}, \mathrm{Cu}, \mathrm{Ni}, \mathrm{Pb}$ and $\mathrm{Zn}$ ) concentration in the soil and eggs which directly affect human health in Mitrovica town's surroundings and to determine its impact and average daily intake dose (ADD) through the food chain, consuming home produced poultry eggs in three different locations in coherence with the impact of the industrial tailings and dumps. Eggs sample were collected from three different poultry farms, and three soil samples from same place in Mitrovica region-Kosovo. The concentration of toxic elements (As, $\mathrm{Cd}, \mathrm{Cr}, \mathrm{Cu}, \mathrm{Ni}, \mathrm{Pb}, \mathrm{Zn}$ ) were analysed by using ICP-OES. Results indicated that on whole egg basis the $\mathrm{As}, \mathrm{Cr}, \mathrm{Ni}, \mathrm{Pb}$ and $\mathrm{Zn}$ content showed 2-3 fold increases than the permissible daily intake level. However the $\mathrm{Cu}$ was within consumable limit while $\mathrm{Cd}$ was undetectable. Results obtained can be used as primary tool to further ensure egg quality control and also can work as dataset for the close monitoring of food contamination by local governments and environmentalist.
\end{abstract}

Key words: Mitrovica, Toxic elements, Soil, Poultry eggs

\section{INTRODUCTION}

Fresh eggs are among the most important nutritious and economical food in the daily diet. Moreover, eggs included in several food products for various functions, are important source of nutrients, containing all of proteins, lipids, vitamins and minerals. However, they are used as evidence for environmental pollution since they can accumulate the toxic elements from diet and the surrounding environment [1]. Environmental pollution through toxic elements lead to an increased interest in contamination of food stuffs and amongst them eggs, which symbolize an important part of human's diet, especially children, as an important source of nutrients, containing all of the protein, lipids, vitamins and minerals. Toxic elements such are metallic elements are found in all living organisms where they perform a variety of roles, as structural, components of mechanisms control (e.g. in nerves and muscles) and enzyme activator. Trace metals like $\mathrm{Cr}, \mathrm{Co}, \mathrm{Cu}, \mathrm{Fe}, \mathrm{Mn}$ and $\mathrm{Zn}$ are essential metals and also called micronutrients and are toxic when taken in excess of requirements [2]. Whereas lead $(\mathrm{Pb})$, Cadmium $(\mathrm{Cd})$ Mercury $(\mathrm{Hg})$ and Arsenic (As) are non-essential metals and toxic even in trace amount. 
Anthropogenic sources of pollution with toxic elements including heavy metals in Mitrovica town in Kosovo region are created during different processes of exploitation of natural resources in Trepça mine, which started big exploration program in 1925, to last until nowadays, but now with most of the Trepça's facilities closed and being limited only in mining and mineral flotation of $\mathrm{Pb}$ and $\mathrm{Zn}$. During this time, in the vicinity of the town in three different locations, were created three huge dumps of different chemical and physical composition containing over 20 millions of tons of hazardous industrial waste; Landfill in a village Kelmend is an active dump of mountainous type that includes an area of around 16 hectares, with around 12 million tons of sterile waste of flotation processes of $\mathrm{Pb}-\mathrm{Zn}$ ore [3], whereas Zveçan is an inactive dump of plain field nature, located at a distance of $1 \mathrm{~km}$ from the town of Mitrovica, with an area of 50 hectares and around 12 million tons of sterile waste - of flotation process in the former flotation plant in Zveçan and in the second part, with about 2,5 million tons of waste of the granulometric scum of the lead smelter. Mitrovica Industrial Park tailings are located in the immediate vicinity of the town and occupies around 35 hectares, containing around 1.5 million tons of waste of phospho-gypsum, jarosite, pyrite and pirotine, then waste which is created by the process of leaching zinc oxide neutral, with high concentration of $\mathrm{Zn} \sim 25 \%, \mathrm{~Pb} \sim 4 \%, \mathrm{Ag} \sim 250 \mathrm{~g} / \mathrm{t}$ and $\mathrm{In} \sim 200 \mathrm{~g} / \mathrm{t}$, being hazardous waste to the environment but also very demanding for reprocessing purposes [3].

The purpose of this paper is to assess the toxic elements including heavy metals $(\mathrm{Cd}, \mathrm{Cu}, \mathrm{Cr}, \mathrm{Pb}$, and $\mathrm{Zn})$ concentration in the soil and eggs which directly affect human health in Mitrovica town's surroundings and to determine its impact and average daily intake dose (ADD) through the food chain, consuming home produced poultry eggs in three different locations in coherence with the impact of the industrial tailings and dumps. Nowadays, after closure of the Zveçan smelter plant in 2000 and closure of phosphoric artificial fertilizers and batteries plant in Mitrovica, these tailings and dumps represent the main source of pollution of soil, water and air with heavy metals in Mitrovica region posing, for decades, potential threat to human health. These toxic elements, such are $\mathrm{Pb}, \mathrm{Cd}, \mathrm{Zn}$ etc. enters the human body through drinking water, food, air, soil, dust, metallurgical and mining industry, etc.[4]. Risks arising from environmental pollution pose any biological, chemical, mechanical agent, being environmental or physical that can damage human health, other organisms or the environment in the absence of its control [4]. The risk is the probability of the occurrence of a negative effect in certain circumstances and is function of a product of the exposure to toxicity.

\section{Risk $=\mathbf{f}($ exposure $\mathbf{X}$ toxicity $)$}

Identification and determination of the risk deriving from environmental pollution is a significant factor in preventing the negative effects. Risk assessment is the process of estimating the potential impact of a chemical, physical, microbiological or psychosocial hazard on a specified human population or ecological system under a specific set of conditions and for a certain time frame being categorised into five distinct stages: Issue identification, Hazard identification, Dose-response assessment, Exposure assessment for the relevant population and Risk characterisation [5][6]. Plants and animals exposed to polluted environment with toxic elements pose a risk for human health as well, since most of them represent a food source, so the toxic elements reach the final destination, human, through the food chain. Exposure to toxic elements can occur as a result of ingestion from food, water and air. This assessment is limited to dietary intake of toxic elements through contaminated home produced poultry eggs.

Toxic elements are chemical elements in our environment to which we are exposed on a daily basis and which become toxic in the body when their intakes exceed the recommended quantities and when they do not dissolve or are not excreted out of the body, so they accumulate in organs and tissues. Eggs samples were collected from three different poultry farms in three different locations while soil samples were also collected at the same 
locations in Mitrovica region. The concentration of toxic elements ( $\mathrm{As}, \mathrm{Cd}, \mathrm{Cr}, \mathrm{Cu}, \mathrm{Ni}, \mathrm{Pb}, \mathrm{Zn}$ ) were analysed by using ICP-OES.

Results indicated that on whole egg basis the $\mathrm{As}, \mathrm{Cr}, \mathrm{Ni}, \mathrm{Pb}$ and $\mathrm{Zn}$ content showed 2-3 fold increases than the permissible daily intake level. However the $\mathrm{Cu}$ was within consumable limit while $\mathrm{Cd}$ was undetectable. Results obtained can be used as primary tools to further ensure egg quality control and also can work as dataset for the close monitoring of food contamination by local governments and environmentalist.

\section{Experimental section}

Sampling site: Determination of the eggs sampling sites is conducted in coherence with the impact of the tailings and dumps in the area as well as concentration of population and their occupation, starting from hotspots, to points with the considerable distance from the potential source of the pollution. All three locations, village Kelmend, village Frashër and 2 Korriku Street (Figure 1.), are densely populated and its inhabitants are predominantly farmers.

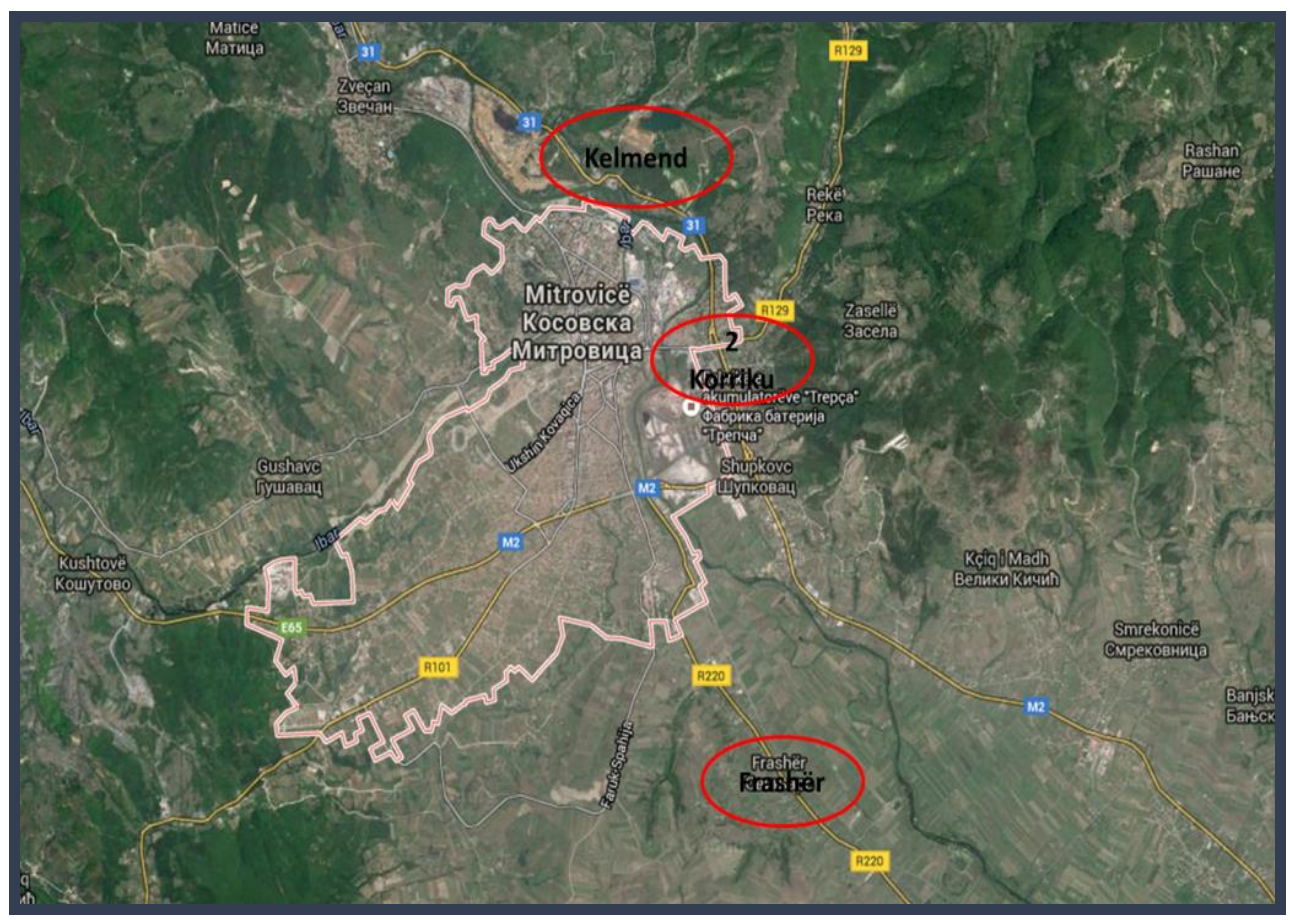

Figure 1. Sample Site Location Map

Samples treatment: All samples were obtained fresh and treated following procedure that includes five processes: 1.Grinding 2. Weighing 3. Mineralisation - dissolution 4.Filtration and 5. Reading. Determination of the presence of toxic elements in these products is conducted with ICP-OES (Inductively Coupled Plasma optical emission spectrometry) that enables determination of several toxic elements' presence at the same time with minimum chemical interference. Each sample is weighted by $2.5 \mathrm{gr}$ and placed in chemically cleaned glass jar adding $9 \mathrm{ml} \mathrm{HNO}_{3}$ and $3 \mathrm{ml} \mathrm{HCl} 35 \%$ and mineralized in a microwave oven. After mineralization samples were placed in clean glass jars and filtered for 10 minutes in a centrifuge. Afterwards samples were placed into volumetric flasks and filled up to $100 \mathrm{ml}$ with distilled water. Determination of toxic elements concentration on a whole hen's egg from the basic volume of the dissolution was conducted with ICP-OES using standard method EPA-6010 C. 


\section{RESULTS AND DISCUSSION}

In order to be in a position to detect toxicity risk, it is necessary to estimate the extent to which living organisms are exposed to contaminants [7]. Based on a soil analyses conducted in 2014, contamination of the soil with toxic elements including heavy metals in the sampling area is significant. Heavy metals analyses have shown high concentration in all samples in all three depths $(10,20$ and $30 \mathrm{~cm})$ in all three locations; In Kelmend village $\mathrm{Pb}$ reaches an average of $2247.4 \mathrm{mg} / \mathrm{kg}, \mathrm{Zn} 1639.35 \mathrm{mg} / \mathrm{kg}, \mathrm{Cu} 158.99 \mathrm{mg} / \mathrm{kg}$ and $\mathrm{Cd}$ an average of $16.51 \mathrm{mg} / \mathrm{kg}$; In "2 Korriku" Street $\mathrm{Pb}$ shows an average concentration in soil of $600 \mathrm{mg} / \mathrm{kg}, \mathrm{Zn} 973.33 \mathrm{mg} / \mathrm{kg}$, Cd $37.33 \mathrm{mg} / \mathrm{kg}$ and $\mathrm{Ni} 115.66 \mathrm{mg} / \mathrm{kg}$; In Frashër village $\mathrm{Pb}$ concentration in soil reaches an average of $3087.35 \mathrm{mg} / \mathrm{kg}, \mathrm{Zn} 976.14 \mathrm{mg} / \mathrm{kg}, \mathrm{Cu} 64.75 \mathrm{mg} / \mathrm{kg}$ and $\mathrm{Cd} 11.27 \mathrm{mg} / \mathrm{kg}$.

Table 1. Heavy metal concentration values obtained from examined soil Samples

\begin{tabular}{|c|c|c|c|c|c|c|}
\hline $\begin{array}{l}\text { Sampling } \\
\text { location }\end{array}$ & $\begin{array}{l}\text { Depth } \\
\text { cm }\end{array}$ & $\mathrm{Pb} \mathrm{mg} / \mathrm{kg}$ & Zn mg/kg & Cu mg/kg & Ni mg/kg & $\underset{\mathrm{mg} / \mathrm{kg}}{\mathrm{Cd}}$ \\
\hline \multirow{3}{*}{2 Korriku } & 10 & 815 & 1300 & $\#$ & 115 & 27 \\
\hline & 20 & 735 & 910 & $\#$ & 110 & 21 \\
\hline & 30 & 250 & 710 & $\#$ & 122 & 64 \\
\hline \multicolumn{2}{|l|}{ Mean } & 600 & 973.333 & & 115.666 & 37.333 \\
\hline \multirow{3}{*}{ Kelmend } & 10 & 1678.31 & 1527.41 & 148.23 & $\#$ & 19.37 \\
\hline & 20 & 1829.49 & 1423.51 & 47.13 & \# & 13.46 \\
\hline & 30 & 3234.4 & 1967.13 & 281.62 & $\#$ & 16.71 \\
\hline Mean & & 2247.4 & 1639.35 & 158.993 & & 16.513 \\
\hline \multirow{3}{*}{ Frashër } & 10 & 7229.09 & 1717.29 & 115.89 & $\#$ & 22.47 \\
\hline & 20 & 1480.06 & 847.81 & 13.62 & $\#$ & 8.08 \\
\hline & 30 & 552.91 & 363.32 & $<10$ & $\#$ & 3.28 \\
\hline \multicolumn{2}{|l|}{ Mean } & 3087.353 & 976.14 & 64.755 & & $\begin{array}{c}11.27666 \\
7 \\
\end{array}$ \\
\hline \multirow{2}{*}{$\begin{array}{l}\text { Maximal } \\
\text { allowable limits } \\
\text { as per: }\end{array}$} & $\begin{array}{c}\text { 86/278/EE } \\
\text { C }\end{array}$ & $50-300$ & $150-300$ & $50-140$ & $30-75$ & $1-3$ \\
\hline & MAL & 100 & 300 & 100 & 50 & 3 \\
\hline
\end{tabular}

Comparing concentration of toxic elements in soil results obtained with the Maximal Allowable Limits MAL and allowed values as per European Union regulation [8][9], concentration of all analysed elements $(\mathrm{Pb}, \mathrm{Zn}, \mathrm{Cd}, \mathrm{Cu}$ and $\mathrm{Ni}$ ) exceeds these values for many times in all three locations, indicating high contamination of the soil (Table 1). Chickens foraging on contaminated soils accumulate these toxic elements into their eggs and, considering the role of egg composition in human nutrition as one of the most important and nutritious food in the daily diet, it is obvious that these elements reach the human body through the food chain. 
Table 2. Mean levels of toxic elements in the examined poultry egg samples

\begin{tabular}{|c|c|c|c|c|c|c|}
\hline \multirow[b]{2}{*}{ Parameters } & \multirow[b]{2}{*}{ Concentration } & \multicolumn{3}{|c|}{ Sampling location } & \multirow[b]{2}{*}{ Mean } & \multirow{2}{*}{$\begin{array}{l}\text { Standard } \\
\text { Deviation }\end{array}$} \\
\hline & & Kelmend & $\begin{array}{c}2 \\
\text { Korriku }\end{array}$ & Frashër & & \\
\hline As & $\mathrm{mg} / \mathrm{kg}$ & 1.83 & 1.47 & 1.98 & 1.76 & 0.262107 \\
\hline $\mathbf{C d}$ & $\mathrm{mg} / \mathrm{kg}$ & $<0.1 \mathrm{ppb}^{*}$ & $<0.1 \mathrm{ppb}^{*}$ & $<0.1 \mathrm{ppb}^{*}$ & $\#$ & $\#$ \\
\hline $\mathrm{Cr}$ & $\mathrm{mg} / \mathrm{kg}$ & 2.61 & 2.20 & 1.6 & 2.137 & 0.508 \\
\hline $\mathbf{C u}$ & $\mathrm{mg} / \mathrm{kg}$ & $<0.4 \mathrm{ppb}^{*}$ & $<0.4 \mathrm{ppb}^{*}$ & $<0.4 \mathrm{ppb}^{*}$ & $\#$ & \# \\
\hline $\mathbf{N i}$ & $\mathrm{mg} / \mathrm{kg}$ & 4.38 & 3.86 & 1.82 & 3.353 & 1.353 \\
\hline $\mathbf{P b}$ & $\mathrm{mg} / \mathrm{kg}$ & 1.58 & 2.62 & 0.64 & 1.613 & 0.990 \\
\hline$\overline{Z n}$ & $\mathrm{mg} / \mathrm{kg}$ & 158.81 & 137.68 & 43.24 & 113.243 & 61.538 \\
\hline
\end{tabular}

${ }^{*}$ Detection level of ICP-OES

Results obtained on the toxic elements content in poultry eggs shown in table 1 demonstrate significant presence of As with an average of $1.76 \mathrm{mg} / \mathrm{kg}, \mathrm{Cr}$ with $2.137 \mathrm{mg} / \mathrm{kg}$, $\mathrm{Ni} 3.353 \mathrm{mg} / \mathrm{kg}, \mathrm{Pb} 1.613 \mathrm{mg} / \mathrm{kg}$ and with $113.243 \mathrm{mg} \mathrm{Zn} / \mathrm{kg}$. Cd and $\mathrm{Cu}$ did not appear to be present. The highest values appear in a sample taken in Kelmend village, located near the active landfill, except $\mathrm{Pb}$ which appears pronouncedly in higher concentration in the sample taken at "2 Korriku" neighborhood. Considering the role of egg in the daily diet, consumption of contaminated eggs with heavy metals represents potential public health hazard, distinctly providing continuing dietary source of toxic elements, causing both, acute and chronic intoxication.

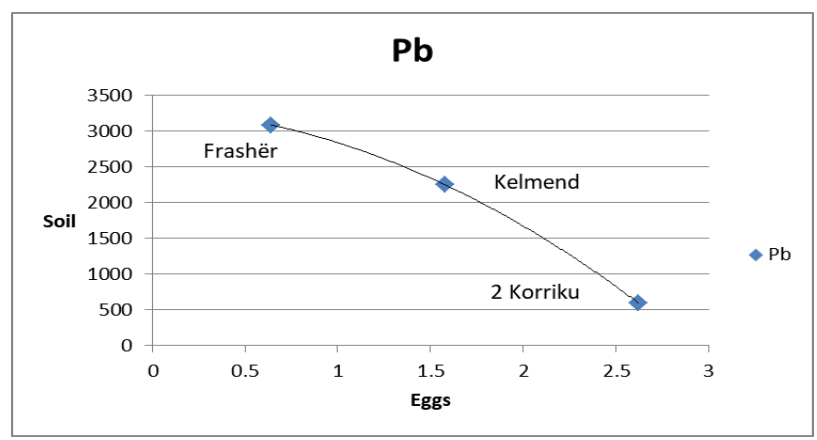

Figure 2. Correlation of concentration of $\mathrm{Pb} \mathrm{mg} / \mathrm{kg}$ in Soil and Egg in all three locations

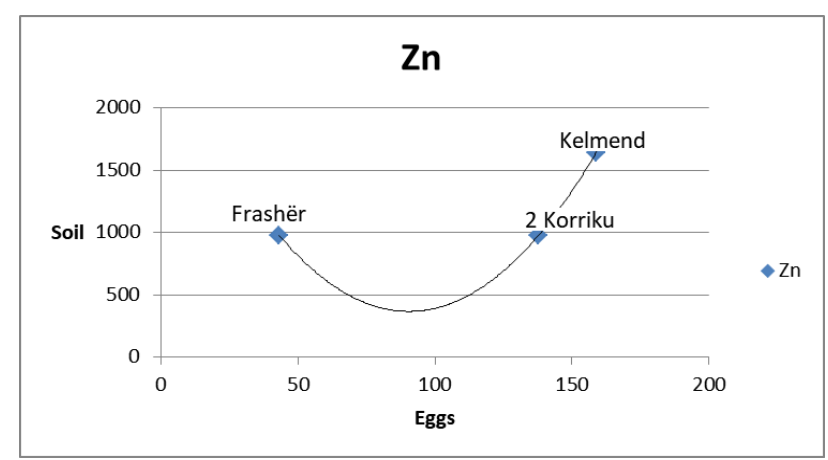

Figure 3. Correlation of concentration of $\mathrm{Zn} \mathrm{mg} / \mathrm{kg}$ in Soil and Egg in all three locations 
The average calculation of daily intake of heavy metals concentrated in poultry eggs is based on assumption of consumption of one egg of the medium size (weighting 60gr) per day, comparing with Tolerable Weekly Intake (TWI) and Acceptable Daily Intake (ADI) recommended by FAO/WHO [9].

Table 3. The average calculation of daily intake of toxic elements concentrated in poultry eggs.

\begin{tabular}{|c|c|c|c|c|c||}
\hline Parameters & $\begin{array}{c}\text { Mean } \\
\mathbf{m g} / \mathbf{k g}\end{array}$ & $\begin{array}{c}\text { TWI } \\
\mathbf{m g} / \mathbf{7 0 k g}\end{array}$ & $\begin{array}{c}\text { ADI } \\
\mathbf{m g} / 70 k g \\
\text { body } \\
\text { weight }\end{array}$ & $\begin{array}{c}\text { Average } \\
\text { weekly intake } \\
\text { consuming } \\
\text { one egg per } \\
\text { day } \\
\text { mg/week }\end{array}$ & $\begin{array}{c}\text { Average daily } \\
\text { intake } \\
\text { consuming } \\
\text { one egg per } \\
\text { day } \\
\text { mg/day }\end{array}$ \\
\hline $\mathbf{A s}$ & $\mathbf{1 . 7 6}$ & & $\mathbf{0 . 1 4 7 *}$ & 0.735 & 0.105 \\
\hline $\mathbf{C d}$ & $\mathbf{N D}$ & & $\mathbf{0 . 0 7}(\mathbf{5 0 5})$ & $\#$ & $\#$ \\
\hline $\mathbf{C r}$ & $\mathbf{2 . 1 3 7}$ & & N/A & 0.896 & 0.128 \\
\hline $\mathbf{C u}$ & $\mathbf{N D}$ & & $\mathbf{3 5 . 0}$ & $\#$ & $\#$ \\
\hline $\mathbf{N i}$ & $\mathbf{3 . 3 5 3}$ & & N/A & 1.407 & 0.201 \\
\hline $\mathbf{P b}$ & $\mathbf{1 . 6 1 3}$ & $0.05(505)$ & N/A & 0.672 & 0.096 \\
\hline $\mathbf{Z n}$ & $\mathbf{1 1 3 . 2 4 3}$ & & $\mathbf{7 0}(\mathbf{6 8 3})$ & 47.53 & 6.79 \\
\hline
\end{tabular}

** Adequate Intakes 19 to 50 years [8]

*** NOAEL [9]

As per results obtained from egg samples analysed in this study, As, $\mathrm{Zn}$ and $\mathrm{Ni}$ is within ADI levels, $\mathrm{Cr}$ exceeds ADI levels for almost four times, $\mathrm{Pb}$ also exceeds for more the eleven times the TWI level.

\section{CONCLUSIONS}

In this study we have introduced the results of the analysis on the presence of toxic elements in soil samples collected in three different locations in and around of industrial zone of Mitrovica and suburb. In order to determine impact of the contamination on food chain we have, in this study, also introduced the results of the presence of toxic elements in chicken eggs collected at the same locations, proving the correlation between soil contamination and presence of toxic elements in eggs.

Determination of the $\mathrm{Pb}$ concentration in a soil samples in this research reveals the fact that impact of the industrial tailing in Mitrovica town is of huge significance when we talk about contamination. From the results obtained in this paper, we can conclude that concentration is much higher in the samples taken in the vicinity of the tailings as is Zvecan and IPM, but also in village Frasher, which is $2 \mathrm{~km}$ away from the nearest tailings (IPM) resulting with highest concentration of $\mathrm{Pb}$ in soil, while in other samples is of lower concentration, but still of concern as it is much above the allowable limits.

Based on the results presented in this study which are essential part of this research we can conclude that: The influence of metallurgical activities of the Trepça units in 
Mitrovica region is significant in terms of environmental pollution with toxic elements, mainly $\mathrm{Pb}, \mathrm{Zn}, \mathrm{Cd}$, but also other metals and metalloids; Dumps created in the past and current activities of the Trepça are the main source of pollution, and pose a permanent health risk to the town of Mitrovica, especially for residents living in the vicinity of the landfills; High level of contamination with toxic elements are found in all samples surveyed in this paper.

Food product analysed in this paper, makes us conclude that the impact of the soil pollution is significant, which is illustrated by the analysis of poultry eggs, what constitute a continuous cycle chain with impact on each other up to human as the user of environment, causing, in many cases, irreversible consequences to the human health. However, though these sources of toxic elements make important contribution and the current assessment was limited to dietary intake, a complete analysis would require addition of non-food sources of toxic elements to the evaluation.

\section{REFERENCES}

1. 1. Z. Vincevica-Gaile,K.Gaga,M.Klavins,APCBEE Procedia 5,2013,p.221-226.

2. M.A. Mora,Environmental Pollution,125,2003,p.393-400.

3. F.Shala, The report of the international conference, 'Industrial waste management of the Trepca enterprise"' Mitrovice,2011,p.19-20.

4. H.W.Sperber, Food Control,4,12,2001 P. 223-228.

5. Australian Government, The Department of Health (DOHA), "Environmental Health Risk Assesment", 2012,P. 3- 9.

6. $\quad$ R.F.Shore,P.E.T.Douben, Environ. Contam. Toxicol., 134,1994,p. 49-89.

7. A.Musliu,Heavy metal in the environment and some food products in the industrial zone of Mitrovica, Kosovo. PhD Thesis, Agricultural University of Tirana, Faculty of Agriculture and Environment, Tirana, Albania,2015.

8. Official Journal of the European Union, L 181/6,Council Directive of 12 June 1986 on the protection of the environment, and in particular of the soil, when sewage sludge is used in agriculture (86/278/EEC), 1986.

9. FAO/WHO,Joint Expert Committee on Food Additives, WHO Technical Report Series No. 505 (1972); No.555 (1974c); No.647 (1980); No.683 (1982); No 751 (1987) and No. 776 (1989).

10. M.Miclean,E.Levei,M.Senila,B.Abraham,C.Roman,C.Emil,STUDIA UNIVERSITATIS BABESBOLYAI,CHEMIA,LIII,3,2008.

11. I.E.Ersoy,A.Uzatici,E.Bilgucu,J.Anim Behav Biometeorol,3,2,2015,p.63-68.

12. U.Guner,Turkish Journal of Biology,34,2010,p.405-412.

13. T.Staszewski,M.Malawska,B.S.Wójcikowska,H. Galera, B. Wiłkomirski,Archives of Environmental Protection, 41,1,2015, p. 35-42.

14. V.Goutner,I.Papagiannis,V.Kalfakakou,The Science of the Total Environment 267,2001,p.169176. 